\title{
Health promotion in coping with COVID-19: a Virtual Culture Circle experience
}

\author{
Promoção da saúde no enfrentamento da COVID-19: experiência de um Círculo de Cultura Virtual \\ Promoción de la salud del enfrentamiento a la COVID-19: experiencia de un Círculo de Cultura Virtual
}

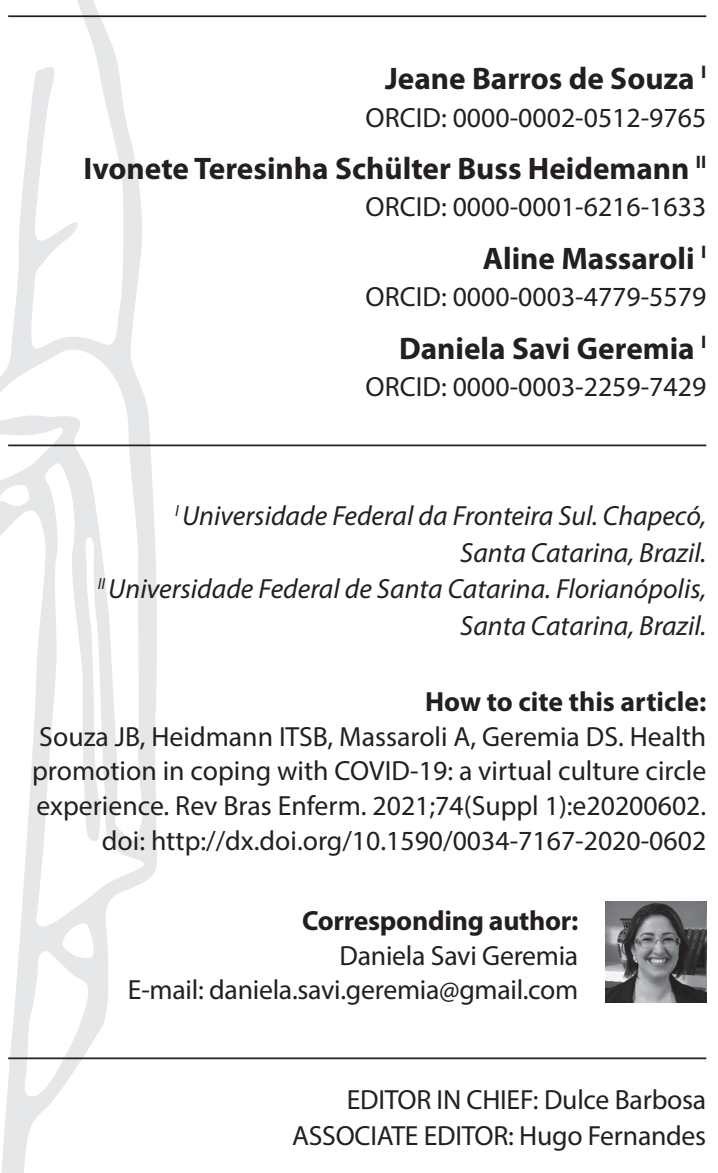

Submission: $04-01-2020$

Approval: 09-20-2020

\begin{abstract}
Objective: To report the experience of a Virtual Culture Circle with Brazilian families about coping with COVID-19, as a space that promotes health during the pandemic. Method: Experience resulting from an extension action, the Virtual Culture Circle was held based on Paulo Freire's Research Itinerary. It counted with the participation of seven families from different locations in Brazil. During the dialogues, a house was built: the foundation represented the thematic research; walls and roof, coding and decoding; doors and windows, the critical unveiling. Results: The action-reflection-action process favored the approach and integration of the participants of the Culture Circle; despite the geographical distance, it is an innovative strategy for empowerment and health promotion. Final considerations: The Virtual Culture Circle constituted a soft technology for health care and can be explored as a tool for promoting health, especially in scenarios where face-to-face meetings are an impossibility. Descriptors: Quarantine; Coronavirus Infections; Health Promotion; Mental Health; Psychological Adaptation, Nursing.
\end{abstract}

\section{RESUMO}

Objetivo: Relatar a experiência de um Círculo de Cultura Virtual com famílias brasileiras sobre o enfrentamento da COVID-19, como espaço promotor da saúde na vivência da pandemia. Método: Experiência oriunda de uma ação extensionista, realizou-se o Círculo de Cultura Virtual, fundamentado no Itinerário de Pesquisa de Paulo Freire. Contou com a participação de sete famílias de diferentes localidades do Brasil. Durante os diálogos, foi construída uma casa: o fundamento representou a investigação temática; paredes e telhado, a codificação e descodificação; portas e janelas, o desvelamento crítico. Resultados: $O$ processo de ação-reflexão-ação favoreceu a aproximação e a integração dos participantes do Círculo de Cultura; apesar da distância geográfica, é estratégia inovadora para empoderamento e promoção da saúde. Considerações finais: O Círculo de Cultura Virtual constituiu-se em uma tecnologia leve para o cuidado em saúde, podendo ser explorado como uma ferramenta para a promoção da saúde, principalmente diante da impossibilidade presencial.

Descritores: Quarentena; Infecções por Coronavírus; Promoção da Saúde; Saúde Mental; Adaptação Psicológica.

\section{RESUMEN}

Objetivo: Relatar experiencia de un Círculo de Cultura Virtual con familias brasileñas frente a la COVID-19, como espacio promotor de salud en la vivencia de la pandemia. Método: Experiencia oriunda de una acción extensionista, se realizó el Círculo de Cultura Virtual, fundamentado en la Investigación de Paulo Freire. Contó con la participación de siete familias de diferentes localidades de Brasil. Durante los diálogos, construyó una casa: el fundamento representó la investigación temática; paredes y techo, la codificación y descodificación; puertas y ventanas, la revelación crítica. Resultados: El proceso de acción-reflexión-acción favoreció la aproximación y la integración de los participantes del Círculo de Cultura; aunque la distancia geográfica, es estrategia innovadora para fortalecimiento y promoción de salud. Consideraciones finales: El Círculo de Cultura Virtual se constituyó en una tecnología leve para el cuidado en salud, pudiendo ser explorado como una herramienta para la promoción de salud, principalmente delante la imposibilidad presencial.

Descriptores: Cuarentena; Infecciones por Coronavirus; Promoción de Salud; Salud Mental; Adaptación Psicológica. 


\section{INTRODUCTION}

2019 ended with unexpected news. A new virus appeared within the Chinese territory which entered the year 2020 causing the infection of an increasing number of people worldwide. It has been termed "severe acute respiratory syndrome coronavirus 2" (SARS-CoV-2). SARS-CoV-2 causes the disease called Coronavirus Disease 2019, known by the abbreviation COVID-19. The number that makes up the name of the disease is related to the fact that the first notification to the World Health Organization (WHO) took place in December 2019(1).

In January 2020, China witnessed the uncontrolled increase in the spread of SARS CoV-2, registering an expressive number of individuals who developed COVID-19, who presented symptoms such as mild respiratory conditions to severe acute respiratory syndrome, the latter requiring intensive care beds and ventilatory support through mechanical ventilation ${ }^{(1)}$. During this period, the world's attention turned to China to follow the development of the disease and the implemented control measures. Within a few days, cases of COVID-19 began to appear in different countries, which were initially related to a contact with the Chinese territory.

The rapid spread of COVID-19 to countries other than China was influenced by the globalization process, which is characterized as a phenomenon that promotes the articulation and interaction of the world through political, cultural, social, and economic issues, making the environment increasingly more complex and dynamic ${ }^{(2)}$. This globalization process facilitates and intensifies the communication and movement of individuals throughout the globe; it is conducive to human development, but it has shown the world that this type of relationship and mobility also entails danger.

In view of the records of dissemination of COVID-19, which quickly surpassed the borders of countries and continents, with the advancement of cases of community transmission of the virus in different countries - that is, when the source of the infection cannot be identified - , the WHO classified COVID-19 as a pandemic in March 2020, which is when a disease is present on five continents, circulating in a large number of countries ${ }^{(3)}$.

With the declaration of a pandemic, worldwide discussions on what would be the most effective measures for the control and prevention of the disease intensified, with a consensus for: the hygiene of hands, surfaces, and environments, respiratory etiquette, additional specific precautionary measures along with the standard precautions in health services, non-sharing of personal objects, detection and isolation of suspected and confirmed cases, in addition to other non-pharmacological measures ${ }^{(3)}$.

Among the non-pharmacological measures, social distancing, isolation, and quarantine stand out. Social distance is indicated for everyone and establishes that individuals must maintain a minimum distance of 2 meters between them, considered a safe distance so that contamination does not occur. Isolation is indicated for symptomatic or asymptomatic cases, with a suspicion or confirmation of the disease, to reduce the contact of these suspected cases with healthy individuals and avoid transmission ${ }^{(4)}$.

Quarantine is determined by the health administrator of a given territory, based on the analysis of the epidemiological profile and capacity of health services to respond to the epidemic, in order to reduce the circulation of people and, thus, slow down the speed of transmission of the disease and the number of sick individuals needing assistance in a hospital and in intensive care beds. This measure becomes even more important in cases of diseases such as COVID-19, which does not have a specific vaccine or medication for its treatment. In Brazil, such action is regulated by Ordinance No. 356, of March 11, 2020(4).

With the advance of community transmission of SARS-CoV-2 and the significant increase in the number of COVID-19 cases, several Brazilian cities and states declared quarantine for its entire population. It was recommended that people stay at home, schools and shops were closed, only services considered essential were allowed to keep functioning, abruptly restricting the relationships that individuals kept in their daily life, whether it be in their work, friendship, family, or religious spheres, among others.

This quarantine movement caused sudden changes in society's life habits and profoundly transformed the routine of individuals and families living in the same house, adding to this turmoil is the restriction of wide social contact and the distancing of several interpersonal relationships, which were previously frequent. Such changes have the potential to cause different feelings and reactions within individuals and families, depending on the way they receive, process and cope with the situation, directly influencing mental health.

The psychological impacts of quarantine have been studied for some time, considering that, in other periods in history, this action has already been instituted in different places for the control of other transmissible diseases. Among the main effects on the mental health of individuals who experience quarantine, the negatives stand out, such as symptoms of post-traumatic stress, confusion, anger, boredom, frustration, anxiety, insomnia, irritability, depressed mood, and fear of being infected. The development of these are influenced by the duration of the quarantine, the access to essential supplies, as well as the person's previous state of mental health ${ }^{(5)}$.

Based on this evidence, actions were also identified to minimize the negative effects of quarantine on the mental health of individuals, such as: making social withdrawal periods as short as possible, providing essential supplies, providing quality information for people to understand the measures that are being implemented, in addition to strategies to reduce boredom and promote communication between individuals. As for the last action, we can emphasize the importance of the internet and of technological resources, which promote the connection and approximation between geographically distant people ${ }^{(5)}$.

In fact, it can be seen that people have expanded the use of technologies to get closer to each other and maintain relationships with their families. Meanwhile, seeking to reflect on the repercussions of quarantine, researchers with experience in the use of Paulo Freire's Culture Circle have used this in a virtual way, as an extension action by a public university in southern Brazil, to establish a connection with some Brazilian families in order to promote health through dialogue, enabling the sharing of experiences.

\section{OBJECTIVE}

To report the experience of a Virtual Culture Circle with Brazilian families as a means to offer a space that promotes health in facing COVID-19. 


\section{METHODS}

\section{Organization of the virtual culture circle}

The experience was based on Paulo Freire's Research Itinerary, which has a liberating pedagogical proposal, takes place through horizontal dialogue, and consists of three dialectic and interconnected moments: thematic research; encoding and decoding; critical unveiling. These stages take place in a space called the Culture Circle, in which each participant brings their own experiences and knowledge, and individuals are active in their learning, involving the participation of all. There is a mediator who develops group interaction to achieve collective knowledge and develop intervention actions ${ }^{(6)}$.

Due to the need for quarantine, it became inevitable to establish the Culture Circle through virtual means. For this purpose, the Zoom ${ }^{\circledast}$ application was used through the cell phone camera, which enabled the families to participate in an interactive way, even though each one was at home. In order to carry out the Culture Circle and maintain a close relationship between those involved, it was decided to first invite a family from the social strata of the authors, to facilitate the interaction and deepen the discussions. Since then, this family has invited other people from its family circle, among brothers, parents, brothers-in-law, grandparents, and friends, to join the Virtual Culture Circle (VCC), so that seven Brazilian families were involved in this process, totaling the participation of 21 individuals, aged between 10 and 82 years.

The seven families reported being middle class and residing in different places in the national territory, being: two in São Paulo, two in Rio de Janeiro, two in Santa Catarina, and one in Goiás. The VCC was held on March 26, 2020, during the quarantine period, with the duration of two and a half hours, mediated by a nurse, doctor, experienced in conducting this type of approach. It should be noted that, on the day before the commencement of the VCC, families were instructed on the use of the application and a test was carried out to verify the connection with everyone involved in the process, adjusting the cell phone's microphone and camera, as well as defining the location within the residence where families would remain during the activity, to provide comfort and allow all members to be seen and heard by the participants in the activity. In addition, each family was asked to have readied a large piece of paper and pens to be used at the meeting.

At first, the proposal was presented to the participants, with an explanation of the work methodology that would be developed at the VCC. The stages of the Research Itinerary were carried out through the analogy of the construction of a house, which depends on all its structures to remain assembled. Then, a puzzle was organized to carry out the construction of the house, adapted by the authors in a playful way, with an aim of making the discussion about coping with COVID-19 more concrete, creative, interactive, and dialogical, as shown in Figure 1.

The house was continuously built during the reflections, remaining physically in the residence of the VCC mediator, who constantly sought the support and interaction of the families in the mission of assembling the puzzle. Thematic research was compared to the fundamentals of the house. To instigate dialogue, it was asked:
"What are the repercussions of the COVID-19 pandemic on your life?"The families dialogued widely and elected two themes for discussion at the VCC, initiating the construction of the house: 1) Quarantine weaknesses; 2) Quarantine potentials.

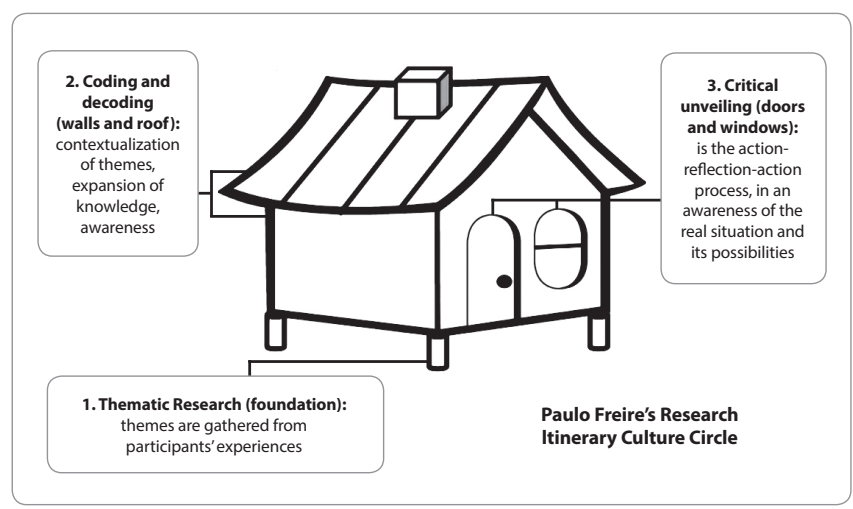

Figure 1 - Stages of the Research Itinerary

For the coding and decoding stage, the walls and roof were built through discussions mediated by two guiding questions: "What are the weaknesses of experiencing quarantine? What are the potentials of experiencing quarantine?" Based on these guiding questions, the families in dialogue at the VCC codified and decoded the generating themes, being asked to write the weaknesses of the quarantine experience on one side of the paper and, on the other side, to register the potentialities that the quarantine provided.

The families presented and discussed their perceptions with the group, giving rise to new significant themes that expressed the situation experienced at the moment; and, while sharing, the mediator wrote down the main reflections, as shown in Figure 2. To validate these records, the mediator read all the notes to the VCC participants, encouraging reflection again on the themes.

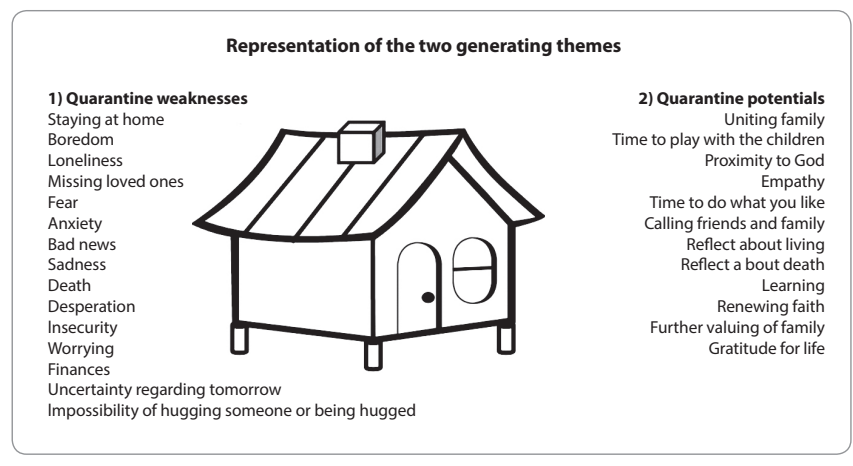

Figure 2 - Two generating themes, which were codified and unveiled at the Virtual Culture Circle with the families

The last stage of the Research Itinerary is the critical unveiling, which took place in an action-reflection-action process of the investigated themes, in which families were invited to express the meaning of experiencing the VCC. At that moment, they built the doors and windows of the house, in the perspective that they represent the internal and external environments of a residence, as was made possible by the participants of the Circle; that is, they were able to look at themselves and subsequently at 
their externalized and built group reflections, to then re-signify the discussions held and empower themselves internally and mutually, strengthening and transforming themselves for the mental health of the whole family in the quarantine experience caused by COVID-19.

From the development of this VCC, a matrix research project was organized to understand the perception of Brazilians about coping and the repercussions of COVID-19 in their lives. It was approved by the Research Ethics Committee.

\section{Virtual Culture Circle: a tool to promote health in times of COVID-19}

Through the VCC dialogues, debates were raised about the daily experiences of quarantine. Thus, the critical-reflective thinking of the participants was widely shared, and the virtual meeting became a dynamic learning space which made it possible to reflect on the existential situations in coping with COVID-19.

Participating families exchanged knowledge during theVCC, being that, when room is made for listening to the needs of individuals, with an opportunity to exchange experiences and information, allowing everyone to share their problems and together seek solutions, such actions make it also an instrument for health promotion in the community ${ }^{(7)}$. In addition, the participants requested other similar moments to further the discussions that emerge when facing COVID-19, and this shows that they intensely enjoyed participating in this space, which provided health for those involved and shared experiences. The fact is that physical isolation is necessary in the context of the pandemic, but not social isolation, that is, it is necessary to stimulate the social interaction of individuals and family members through electronic devices that promote communication, interaction, and health, just as it was done in this experiment.

It can be seen that, in general, researchers and scientists have actively been seeking information regarding COVID-19 in order to achieve greater possibilities for the cure of affected individuals and the prevention of new cases, which is healthy and extremely relevant in the current situation. However, attention is drawn to researchers and health professionals so they can also look at individuals, families, and communities facing the current situation, seeking strategies to promote health in times of pandemic, as it is believed that the repercussions of this moment of crisis will extend over a long period of time in the way of life of both the individuals and the communities.

In this scenario, it is necessary to transpose the current biomedical model and promote health as a benefit and a right of every citizen, being that the conceptions and practices regarding illness can hinder the possibilities of doing health based on the ways of being and living in society. It is worth remembering that the concept of health promotion resulted from the Ottawa Charter of 1986, defining how the process of qualifying individuals and communities to act to improve their quality of life, considering the importance of social determinants of health ${ }^{(8)}$.

Furthermore, for the Culture Circle to be virtual or presential, to become a health-promoting space, it is suggested that the mediator organize a creative and playful strategy to cover the stages of the Freirean Itinerary, in order to get closer to the reality of the participants in a concrete way, establishing a greater connection with them. The playful during the educational process activates the interaction and the construction of knowledge together, enhancing the protagonism of those involved in the activity and the exercise of autonomy, with expression of feelings and ideas ${ }^{(9)}$. In the experience reported here, the representation of the house was chosen because it allows the reflection of the situation of the participating families, who were quarantined in their homes during the period of the VCC; this made the discussion more concrete, creative, interactive, dialogical, close to the reality of the participants, as well as making it possible to carry out all the phases of Paulo Freire's Itinerary in a single meeting.

In this context, the VCC presents itself as a soft technology for care, being an innovative and creative strategy that emerged due to the impositions and limitations brought by COVID-19, as it enabled the dialogue between families that were distant, allowing social approximation, reflection and learning in an agile way and with scarce resources, in a pandemic period. The use of soft technologies in the field of nursing has gained prominence, with the opportunity to develop them in favor of the growth of the profession. They are produced in the work process, condensing the relationships of subjectivity, interaction, generating welcoming, bonding, and autonomy in the meetings between health professionals and individuals who need care ${ }^{(10)}$.

Therefore, as a suggestion, the development of welcoming opportunities for individuals through the VCC is emphasized to promote health. These spaces must prioritize the exchange of knowledge and provide dialogue, empowerment and hope for individuals, families, communities, both nationally and worldwide. In this regard, nursing stands out as a potential strategy for dialogue between communities and health care, being able to act in their territory through intersectoral actions, mainly in Primary Health Care, thus seeking to promote health in its broadest sense.

\section{Study limitations}

This experience was limited by the fact that it was the authors' first experience in the development of the Culture Circle through the virtual environment, being that future opportunities could be conducted with greater tranquility and security, providing new perspectives on this strategy.

\section{Contributions to the field of nursing, health, or policies}

Based on the successful experience reported by the researchers, this work represents an innovation in the way of developing the Culture Circle, as it allows to extrapolate the limits of the presence of all participants within the same physical space, expanding the opportunities for using this methodological strategy as a soft technology for care.

In addition, it enables the practice of listening with acceptance, the exchange of experiences and information to be instruments for promoting health and well-being in families, even if geographically distant. Therefore, the accomplishment of the VCC, based on Paulo Freire's referential, emerged as a methodological and assistance tool for nursing, and through liberating dialogic actions, it allowed the development of humane, comprehensive, and welcoming care, given the need for social restriction. 


\section{FINAL CONSIDERATIONS}

The VCC, supported by Paulo Freire's theoretical-philosophicalpolitical assumptions, provided a space for embrace and horizontal dialogue, promoting participants' health by enabling a feeling of trust, construction of knowledge, freedom of expression, love, hope. This allowed us to critically reflect on life and its consequences, becoming aware of its existence, with a re-elaboration of the knowledge of its reality in the experience of the quarantine generated by COVID-19.

It can be seen that the development of the VCC was a fruitful strategy, as it favored the approach of the participants without the need of physical contact, enabling the integration of geographically distant people. This innovative VCC execution presents itself as a potential to promote the health of individuals and of collectivity in times of pandemic, as well as for the realization of an actionparticipant research with the involvement of individuals regardless of their geographic location. It is also suggested to carry out studies that can deepen the possible characteristics of differing in both strategies, the in-person Culture Circle and the VCC.

\section{FUNDING}

This research was supported by the Coordination for the Improvement of Higher Education Personnel (CAPES - Coordenação de Aperfeiçoamento de Pessoal de Nível Superior).

\section{REFERENCES}

1. Guinai I, McPherson TD, Hunter JC, Kirking HL, Christiansen D, Joshi K, et al. First known person-to-person transmission of severe acute respiratory syndrome coronavirus 2 (SARS-CoV-2) in the USA. Lancet. 2020;S0140-6736(20)30607-3. doi: 10.1016/S0140-6736(20)30607-3

2. Celano AC, Guedes AL. Impactos da globalização no processo de internacionalização dos programas de educação em gestão. Cad EBAPE.BR [Internet]. 2014[cited 2020 Mar 29];12(1):45-61. Available from: http://www.scielo.br/pdf/cebape/v12n1/v12n1a05.pdf

3. Ministério da Saúde (BR). Secretaria de Vigilância em Saúde. Centro de Operações Emergenciais em Saúde Pública. Boletim Epidemiológico 04 - COE COVID-19, 04 de março de 2020 [Internet]. Brasília: MS; 2020 [cited 2020 Mar 29]. Available from: https://www.saude.gov.br/ images/pdf/2020/marco/04/2020-03-02-Boletim-Epidemiol--gico-04-corrigido.pdf

4. Ministério da Saúde (BR). Portaria № 356, de 11 de março de 2020. Dispõe sobre a regulamentação e operacionalização do disposto na Lei n 13.979, de 6 de fevereiro de 2020, que estabelece as medidas para enfrentamento da emergência de saúde pública de importância internacional decorrente do coronavírus (COVID-19) [Internet]. Brasília: MS; 2020 [cited 2020 Mar 29]. Available from: http://www.in.gov.br/ en/web/dou/-/portaria-n-356-de-11-de-marco-de-2020-247538346

5. Brooks SK, Webster RK, Smith LE, Woodland L, Wessely S, Greenberg N, et al. The psychological impact of quarantine and how to reduce it: rapid review of the evidence. Lancet. 2020;395:912-20. doi: 10.1016/ S0140-6736(20)30460-8

6. Heidemann ITSB, Dalmoni IS, Rumor PCF, Cypriano CC, Costa MFBNA, Durand MK. Reflexões sobre o Itinerário de Pesquisa de Paulo Freire: contribuições para a saúde. Texto Contexto Enferm. 2017;26(4):e0680017. doi: 10.1590/0104-07072017000680017

7. Menezes KKP, Avelino PR. Grupos operativos na Atenção Primária à Saúde como prática de discussão e educação: uma revisão. Cad Saúde Colet. 2016;24(1):124-30. doi: 10.1590/1414-462X201600010162

8. Ivo MAS, Malta DC, Freitas MIF. Modos de pensar dos profissionais do Programa Academia da Saúde sobre saúde e doença e suas implicações nas ações de promoção de saúde. Physis: Rev Saúde Coletiva. 2019;29(1):e290110 doi: 10.1590/S0103-73312019290110

9. Souza JB, Colliselli L, Madureira VSF. A utilização do lúdico como estratégia de inovação no ensino da enfermagem. Rev Enf C-Oeste Mineiro. 2017;7:e1227. doi: 10.19175/recom.v7i0.1227

10. Moraes de Sabino LM, Brasil DRM, Joselany ÁC, Santos MCL, Santos Alves MD, et al. The Use of Soft-Hard Technology in Nursing Practice: Concept Analysis. Aquichan. 2016;16(2):230-9. doi: 10.5294/aqui.2016.16.2.10 